Prepared for the U.S. Department of Energy

under Contract DE-AC05-76RL01830

\title{
300 Area Integrated Field-Scale Subsurface Research Challenge (IFRC) Field Site Management Plan
}

MD Freshley

November 2008 


\title{
DISCLAIMER
}

This report was prepared as an account of work sponsored by an agency of the United States Government. Neither the United States Government nor any agency thereof, nor Battelle Memorial Institute, nor any of their employees, makes any warranty, express or implied, or assumes any legal liability or responsibility for the accuracy, completeness, or usefulness of any information, apparatus, product, or process disclosed, or represents that its use would not infringe privately owned rights. Reference herein to any specific commercial product, process, or service by trade name, trademark, manufacturer, or otherwise does not necessarily constitute or imply its endorsement, recommendation, or favoring by the United States Government or any agency thereof, or Battelle Memorial Institute. The views and opinions of authors expressed herein do not necessarily state or reflect those of the United States Government or any agency thereof.

\author{
PACIFIC NORTHWEST NATIONAL LABORATORY \\ operated by \\ BATTELLE \\ for the \\ UNITED STATES DEPARTMENT OF ENERGY \\ under Contract DE-AC05-76RL01830
}

Printed in the United States of America

Available to DOE and DOE contractors from the

Office of Scientific and Technical Information,

P.O. Box 62, Oak Ridge, TN 37831-0062;

ph: (865) 576-8401

fax: (865) 576-5728

email: reports@adonis.osti.gov

\author{
Available to the public from the National Technical Information Service, \\ U.S. Department of Commerce, 5285 Port Royal Rd., Springfield, VA 22161 \\ ph: (800) 553-6847 \\ fax: (703) 605-6900 \\ email: orders@ntis.fedworld.gov \\ online ordering: http://www.ntis.gov/ordering.htm
}

This document was printed on recycled paper. 


\section{Area Integrated Field-Scale Subsurface Research Challenge (IFRC) Field Site Management Plan}

MD Freshley

November 2008

Prepared for

the U.S. Department of Energy

under Contract DE-AC05-76RL01830

Pacific Northwest National Laboratory

Richland, Washington 99352 



\section{Revision Log}

\begin{tabular}{|c|c|c|c|}
\hline Revision & Date & Author(s) & Summary of Changes \\
\hline Revision 0 & July 26, 2007 & MD Freshley & Revision 0 \\
\hline Revision 1 & February 28, 2008 & MD Freshley & $\begin{array}{l}\text { Update of facility where laboratory } \\
\text { analyses of samples will be performed; } \\
\text { UIC well registration }\end{array}$ \\
\hline Revision 2 & December 4, 2008 & MD Freshley & $\begin{array}{l}\text { Update to reflect well network } \\
\text { installation }\end{array}$ \\
\hline
\end{tabular}





\section{Acknowledgements}

This research is funded by the Environmental Remediation Sciences Program, Environmental Remediation Sciences Division, Biological and Environmental Research, U.S. Department of Energy. 



\section{Acronyms and Abbreviations}

$\begin{array}{ll}\text { BER } & \text { Biological and Environmental Research } \\ \text { CERCLA } & \text { Comprehensive Environmental Response, Compensation, and Liability Act } \\ \text { CX } & \text { Categorical Exclusion } \\ \text { DOE } & \text { U.S. Department of Energy } \\ \text { DOT } & \text { U.S. Department of Transportation } \\ \text { DWS } & \text { Drinking Water Standard } \\ \text { Ecology } & \text { Washington State Department of Ecology } \\ \text { EM } & \text { Environmental Management } \\ \text { EPA } & \text { U.S. Environmental Protection Agency } \\ \text { EPR } & \text { Electronic Prep and Risk } \\ \text { ERSD } & \text { Environmental Remediation Sciences Division } \\ \text { ERSP } & \text { Environmental Remediation Sciences Program } \\ \text { ES\&H } & \text { Environment, Safety, and Health } \\ \text { FSM } & \text { Field Site Manager } \\ \text { HAZWOPER } & \text { Hazardous Waste Operations and Emergency Response } \\ \text { IFRC } & \text { Integrated Field-Scale Subsurface Research Challenge } \\ \text { ISMS } & \text { Integrated Safety Management System } \\ \text { NEPA } & \text { National Environmental Policy Act } \\ \text { ORP } & \text { Office of River Protection } \\ \text { PAAA } & \text { Price Anderson Amendments Act } \\ \text { PI } & \text { Principal Investigator } \\ \text { PNNL } & \text { Pacific Northwest National Laboratory } \\ \text { PNSO } & \text { Pacific Northwest Site Office } \\ \text { QAP } & \text { Quality Assurance Plan } \\ \text { RL } & \text { Richland Operations Office } \\ & \end{array}$





\section{Contents}

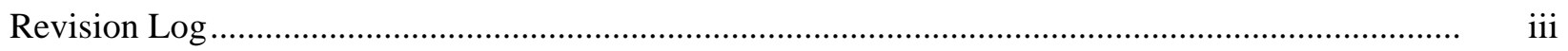

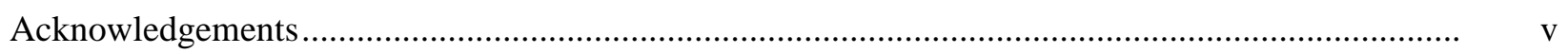

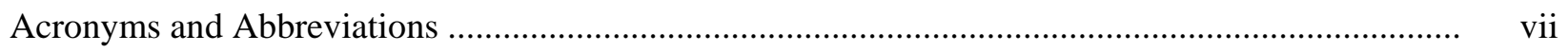

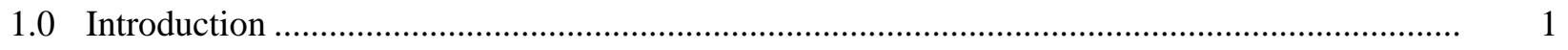

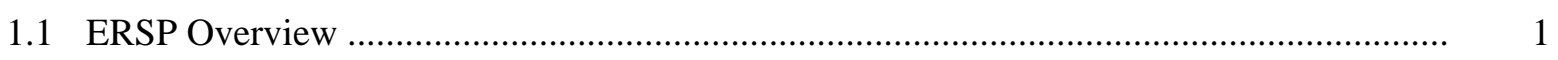

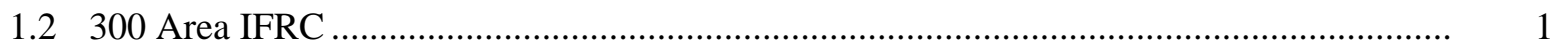

2.0 Field Site Management Approach ….......................................................................... 5

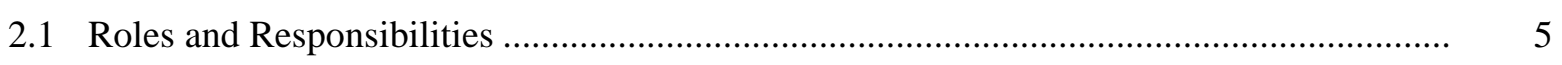

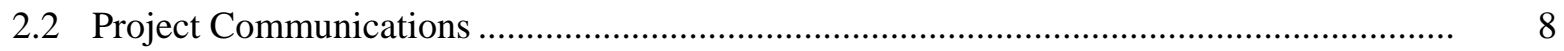

2.3 Environment, Safety, and Health ............................................................................... 8

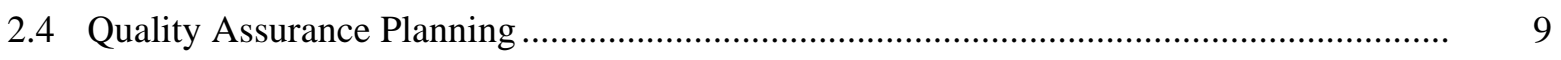

2.4.1 Personnel Training and Qualification................................................................... 10

2.4.2 Document and Records Management.................................................................. 10

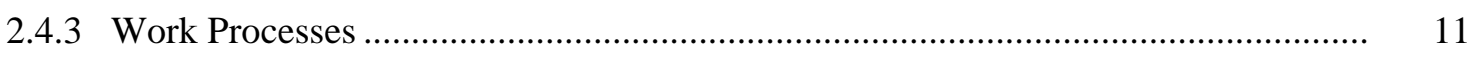

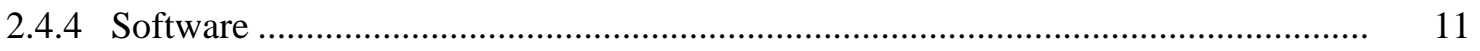

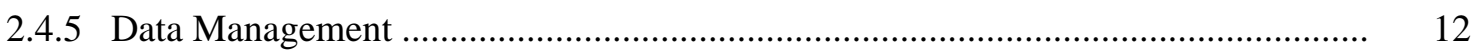

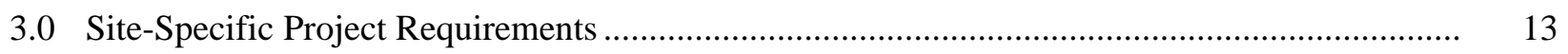

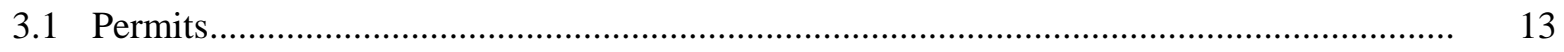

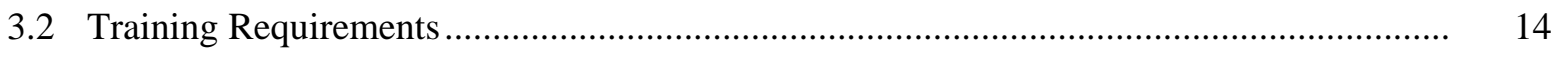

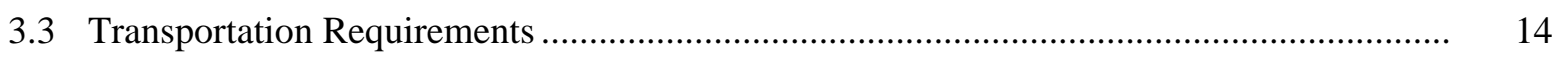

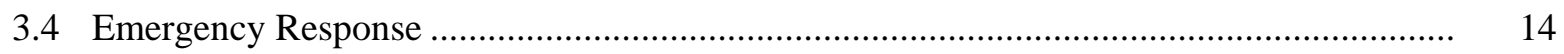

4.0 Access for ERSD Investigators Not Participating Directly in the 300-Area IFRC .................... 15

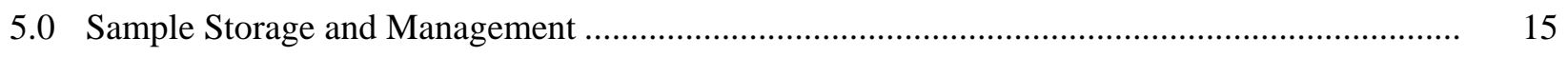

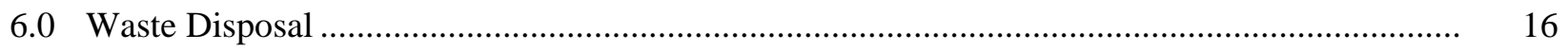

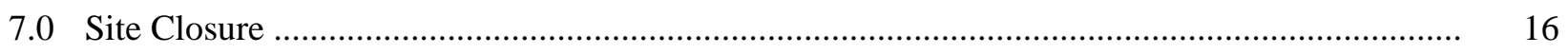

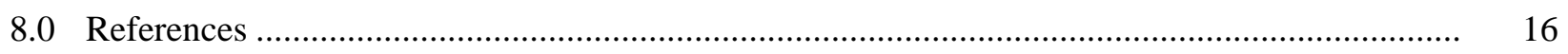

Appendix A - Contact List for the 300 Area IFRC ...................................................................... A.1

Appendix B - PNSO and DOE Richland Approval Letters for Use of 300 Area by IFRC................. B.1 


\section{Figures}

1 Hanford Site Groundwater Interest Areas and Operable Units................................................... 2

2 Planned Configuration of the 300 Area IFRC Within the South Process Pond............................ 3

\section{Tables}

1 IFRC Staff Roles and Responsibilities ........ 


\subsection{Introduction}

Pacific Northwest National Laboratory (PNNL) has established the 300 Area Integrated Field-Scale Subsurface Research Challenge (300 Area IFRC) on the Hanford Site in southeastern Washington State for the U.S. Department of Energy's (DOE) Office of Biological and Environmental Research (BER) within the Office of Science. The project is funded by the Environmental Remediation Sciences Division (ERSD) through the Environmental Remediation Science Program (ERSP) Notice LAB 06-16.

\subsection{ERSP Overview}

For more than 60 years, the United States used a network of facilities for research, development and testing of nuclear materials. These activities left DOE with a nuclear weapons complex with extensive surplus facilities and associated contaminated land (DOE 1997, 1999). Radioactive wastes are stored at several of the DOE sites, and a large total volume of soil, groundwater, and sediment is contaminated with complex mixtures of radionuclides, metals, and organic contaminants (DOE 1997 and 1999). These wastes and their environmental remediation are managed by the DOE Office of Environmental Management (EM).

Within the context of cleaning up the nuclear waste legacy, BER has a long tradition of supporting fundamental research focused on DOE's environmental problems. For nearly two decades, research has been underway to understand and utilize natural processes for remediating contaminated DOE EM lands. The stated mission of ERSD is

To advance our understanding of the fundamental biological, chemical, and physical processes that control contaminant behavior in the environment in ways that help solve DOE's intractable problems in environmental remediation and stewardship.

The fundamental nature of the research ensures that results will be broadly applicable to other DOE missions. The mission is accomplished through hypothesis-driven, discovery-based fundamental research implemented by competitively awarded, peer-reviewed research projects at scientific institutions nationwide. These projects are complemented by scientific user facilities and research sites that provide unique opportunities to understand the physical, chemical, and biological nature of our environment. The 300 Area IFRC is one of the research sites.

\subsection{Area IFRC}

The purpose of the project is to conduct research at the 300 IFRC (Figure 1) to investigate multi-scale mass transfer processes associated with a subsurface uranium plume impacting both the vadose zone and groundwater. The field site is located within the 300-FF-1 waste site and 300-FF-5 groundwater Comprehensive Environmental Response, Compensation, and Liability Act (CERCLA) operable units. 


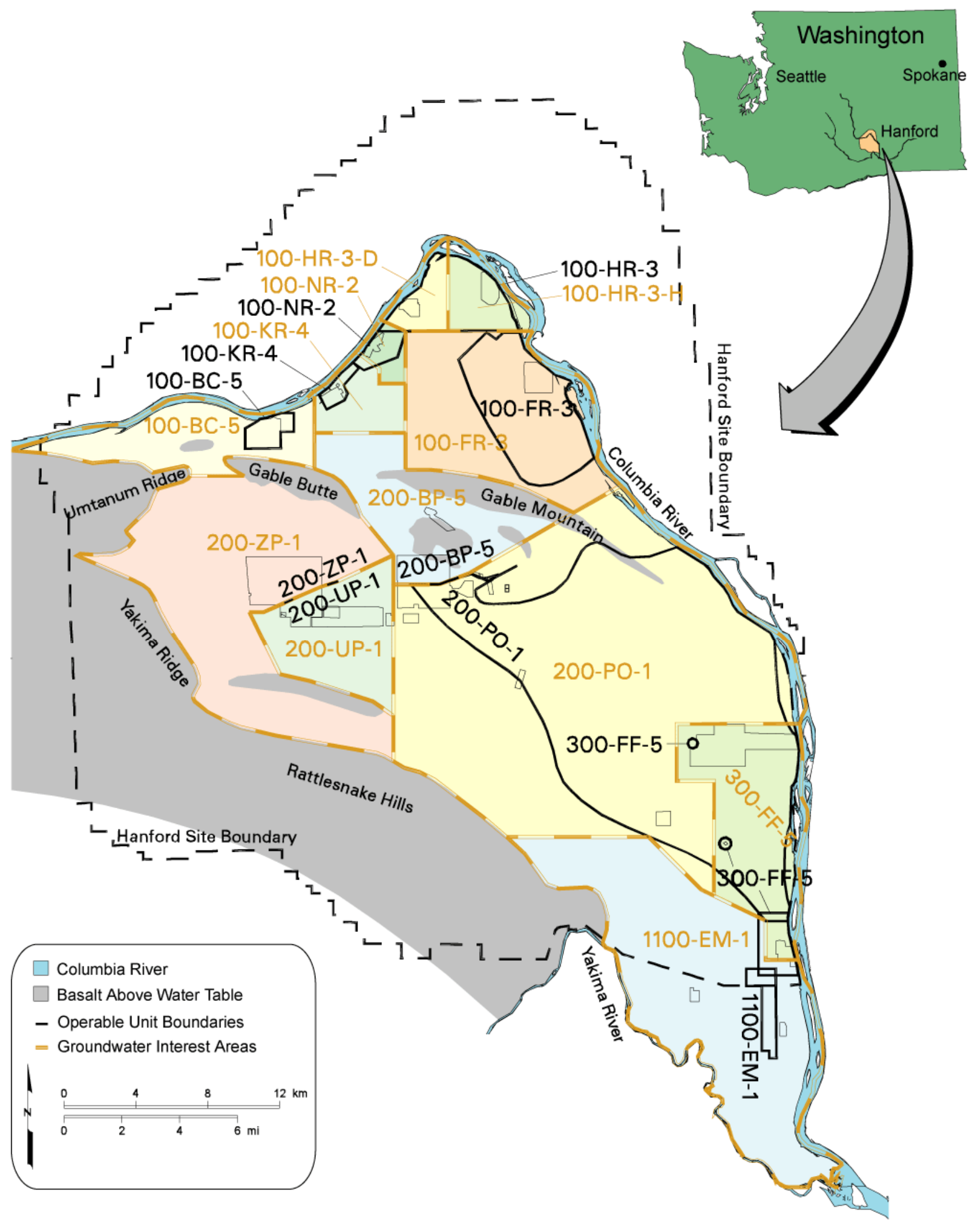

can_gwf03_641 Fobruary 18, 2004 4:49 PM

Figure 1. Hanford Site Groundwater Interest Areas and Operable Units 
The 300 Area of the Hanford Site was selected for locating an IFRC because it offers excellent opportunities for field research on the influence of mass-transfer processes on uranium in the vadose zone and groundwater. The 300 Area was the location of nuclear fuel fabrication facilities and has more than 100 waste sites (Gephart 2003). Two of these waste sites, the North and South Process Ponds, received large volumes of process waste from 1943 to 1975 . The two process ponds represent a significant source of the groundwater uranium plume in the 300 Area. Geophysical surveys and other characterization efforts led to the selection of the South Process Pond for the IFRC (Figure 2).

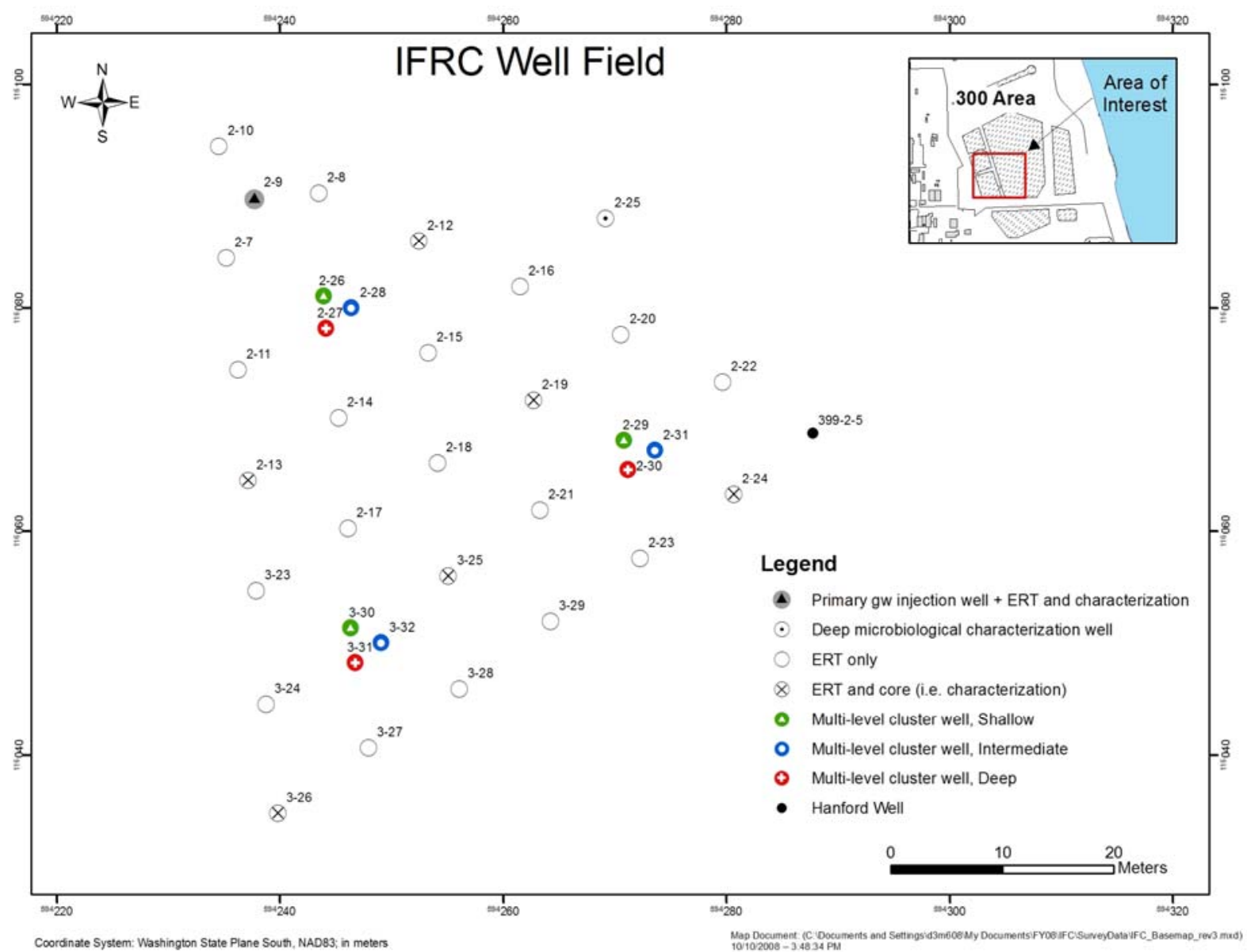

Figure 2. Planned Configuration of the 300 Area IFRC Within the South Process Pond

Large volumes of process waste from fabrication of nuclear fuels were deposited in the northern part of the 300 Area in the two process ponds and at other waste sites. The wastes included acids (nitric, sulfuric, and hydrofluoric) containing uranium, strontium-90, zirconium, copper, and beryllium in addition to chemicals such as nitrate, trichloroethylene, and dichloroethene (Gephart 2003). The important waste streams were low-pH copper/uranyl nitrate solutions and high-pH sodium aluminate solutions. The disposed inventory includes uranium (33,600-59,000 kg), copper (241,300 kg), aluminum $(113,400 \mathrm{~kg})$, nitrate $(2,060,700 \mathrm{~kg})$ and large volumes of acid and base.

Wells have been installed in the 300 Area since the early 1940s for subsurface characterization and monitoring. The monitoring network has been expanded in response to growing concerns regarding the 
uranium plume and attendant CERCLA investigations. Aquifer testing and other hydrologic investigations have been performed along with geologic characterization and both surface and borehole geophysics.

Two CERCLA Operable Units exist in the 300 Area. The 300-FF-1 Operable Unit includes the waste disposal sites themselves as well as the shallow vadose zone. As part of the record of decision for the waste sites, shallow contaminated sediments were excavated from the process ponds and trenches between 1995 and 2004 as a source control measure to minimize additional groundwater contamination. The excavated process ponds were backfilled, the land surface regarded to a natural state, and the site reclaimed.

The 300-FF-5 Operable Unit includes the deep vadose zone contamination that remains and the groundwater. In 1996, an interim CERCLA remedy was selected to monitor the uranium plume in groundwater based on equilibrium distribution coefficient $\left(\mathrm{K}_{\mathrm{d}}\right)$ modeling that implied the natural processes of groundwater flushing and desorption would decrease the uranium concentrations below the drinking water standard (DWS) within ten years. Subsequent monitoring has documented that the uranium concentrations in groundwater are not decreasing as projected but remain above the DWS throughout much of the 300 Area. As a result of the ineffectiveness of the interim remedy, DOE-EM through the Richland Operations Office (RL) initiated a Phase III Feasibility Study for 300-FF-5 in 2005. The feasibility study includes a limited field investigation (DOE 2005) to define the depth-distribution of uranium in the aquifer and capillary fringe and to further characterize the hydrogeologic properties of the unconfined aquifer and the topography and hydrogeology of the Hanford-Ringold formation contact. Sonic drilling was used to recover continuous and intact large-diameter sediment core from four limited field investigation boreholes in 2006. Depth-discrete groundwater sampling and aquifer testing were performed to delineate the distribution of uranium contamination and hydrologic flow parameters in the unconfined aquifer. The DOE-EM Office of Engineering and Technology (EM-22) funded a project to perform a field-scale feasibility experiment that is underway to induce the precipitation of autunite by polyphosphate injection to lower uranium concentrations and apatite and prevent future uranium contamination from the capillary fringe from migrating to the unconfined aquifer.

A combination of projects funded by DOE-RL and ERSD has completed detailed scientific characterization of the 300 Area materials. When the process pond excavations were open in 2004, two pits were excavated to groundwater in each of the process ponds, and the depth profile of these materials was studied in detail. These laboratory geochemical studies, focused at the microscopic scale, have sought to quantify pore-scale contaminant behavior. Detailed hydrogeologic investigations have also been performed, including laboratory physical property characterization and subsurface geophysics, to characterize heterogeneity as well as reactive transport modeling to incorporate new knowledge into projections of uranium transport.

The 300 Area IFRC project complements and builds on the work of these other projects. To motivate the research, science questions on mass transfer are posed related to the effect of spatial heterogeneities, scale, and coupled interactions between biogeochemistry and hydrogeology. These questions are being resolved through evaluation of three site-specific field hypotheses using infiltration, injection, and downwell experiments and monitoring arrays aligned along natural gradients that develop and evolve in the 300 Area and influence the uranium plume. The field site has been designed to take advantage of seasonal gradients and head reversals in the aquifer that are driven by stage fluctuations of the Columbia River. 


\subsection{Field Site Management Approach}

The management approach for the 300 Area IFRC requires close collaboration and communication between participants on the project, other ERSD investigators, and field activities funded by DOE-RL and EM-22. The 300 Area IFRC project team members collaborate extensively to conduct field and laboratory experiments, share information and data, and publish results.

ERSD researchers who are not directly associated with the 300 Area IFRC have access to the site and associated resources to conduct work. All project team members and other ERSD investigators accessing the field site are required to be trained on the procedures for conducting field work at the site. The 300 Area IFRC project has created a set of plans to document and control work:

- Field Site Management Plan (this document)

- Field Site Characterization Plan

- Scientific Research Plan (Implementation Plan) and Schedule

- Health and Safety Plan

- Quality Assurance/Quality Control Plan

- Communication Plan

- Field Site Closure Outline (to be prepared).

\subsection{Roles and Responsibilities}

The 300 Area IFRC includes a Principal Investigator (PI) (John Zachara), a Field Site Manager (FSM) (Mark Freshley), and a core research team. All members of the core research team for the 300 Area IFRC report to the PI, who is also the project manager. The FSM reports directly to the PI and is responsible for managing and coordinating field activities, ensuring compliance with environment, safety and health (ES\&H) requirements, and managing field staff and infrastructure. The FSM is responsible for obtaining and maintaining appropriate permits for conducting field work at the site and coordinating with other ongoing field research activities in the 300 Area.

Several offices within DOE are involved in the 300 Area IFRC. DOE ERSD provides funding for the project through ERSP and oversight for conduct of the research. David Lesmes is the ERSD Program Manager assigned to the 300 Area IFRC. PNNL reports to the DOE-Office of Science (SC) Pacific Northwest Site Office (PNSO), which provides operational oversight of research. DOE-RL is responsible for operation and remediation of the 300 Area and thus provides permission for the 300 Area IFRC to operate in the 300 Area and provides general project support and an interface to remediation activities that are underway.

The 300 Area IFRC subcontracts with the Hanford Site Soil and Groundwater Remediation Project (currently CH2M Hill Plateau Remediation Contract) for drilling and construction activities. Drilling activities include subcontracting with well drillers, sample recovery, well completion, compliance with Washington State regulations, and waste management during drilling operations. The Soil and Groundwater Remediation Project also provides excavation services for construction of the vadose zone infiltration facility as well as decommissioning of the experimental site at the end of the project. 
The 300 Area IFRC also interfaces with the River Corridor Contractor (Washington Closure, Hanford, LLC), who is responsible for surface remediation and demolition of buildings in the 300 Area. The River Corridor Contractor is notified of activities ongoing at the 300 Area IFRC and provides approval for personnel working on the project.

The specific roles and responsibilities for the organizations that support the 300 Area IFRC are listed in Table 1.

Table 1. IFRC Staff Roles and Responsibilities

Position: 300 Area IFRC Principal Investigator (PI)

Organization: PNNL

Staff Member: John Zachara

- Manages the 300 Area IFRC site and research operations

- Supervises IFRC staff and subcontractors

- Interacts with DOE ERSD, DOE-RL, and its subcontractors, Washington Closure Hanford and Fluor Hanford, to plan and conduct work

- Develops and maintains the overall Scientific Research Plan and schedule

- Participates in quarterly conference calls with the ERSD program manager

- Submits quarterly progress reports to the ERSD program manager

- Provides state-of-the-art equipment and knowledgeable staff to perform field experiments at the IFRC

- Leads publications of scientific research results from field experiments at the IFRC

- Assists the ERSD program manager with transfer of knowledge and technology to DOE-EM, primarily DOERL, for making progress on remediation of DOE sites.

Position: 300 Area IFRC Field Site Manager (FSM)

Organization: PNNL

Staff Member: Mark Freshley

- Manages the 300 Area IFRC site operations including obtaining applicable permits, preparing and implementing site safety plans, scheduling field activities and operations, and supervising IFRC staff and subcontractors in the field

- Co-manages the 300 Area IFRC site and research operations

- Supervises IFRC staff and subcontractors during field operations

- Establishes and maintains management and operating procedures for the IFRC

- Approves work plans for all field activities at the IFRC before initiation

- Monitors field operations at the IFRC

- Oversees collection, tracking, and documentation of field samples

- Distributes groundwater and sediment materials to other IFRC participants and ERSD investigators as requested.

- Participates in quarterly conference calls with the ERSD program manager

- Contributes to quarterly progress reports to the ERSD program manager

- Provides state-of-the-art equipment and knowledgeable staff to perform field experiments at the IFRC.

Position: 300 Area IFRC Investigators

Organization: PNNL and others

Staff Member: Various

- Participate in 300 Area IFRC research activities

- Review and follow the 300 Area IFRC Field Site Management Plan (this document), Health and Safety Plan, Quality Assurance Plan, Research Plan, Site Characterization Plan, and the Communications Plan

- Submit preliminary work plans and full work plans for both sampling and in situ research to the PI and FSM

- Participate in field experiments at the IFRC

- Provide periodic reports to the IFRC PI and FSM on activities and necessary training certification

- Provide data and results in a timely manner to the IFRC PI. 
Table 1. (contd)

Position: 300 Area IFRC Environmental Remediation Science Division (ERSD) Program Manager

Organization: DOE Office of Biological and Environmental Research, ERSD

Staff Member: David Lesmes

- Works with the ERSD program managers, PNSO, and PNNL to provide funding and support to the 300 Area IFRC

- Oversees activities at the IFRC

- Approves the 300 Area IFRC Field Site Management Plan (this document), Health and Safety Plan, Quality Assurance Plan, Research Plan, Site Characterization Plan, and the Communications Plan

- Reviews the Health and Safety Plan for the 300 Area IFRC

- Reviews the DOE Field Work Proposal for IFRC funding and provides budget

- Participates in quarterly conference calls and reviews quarterly progress reports

- Ensures that field-scale activities are linked to the goals of the ERSD Strategic Plan through 1) focused research efforts designed to transfer knowledge and technologies to DOE-EM and 2) promoting development and testing of tools and methods for field or laboratory analysis and monitoring

- Promotes linkages and data dissemination among DOE programs (e.g., other ERSD projects, DOE-EM) and other federal agencies to maximize the success of the IFRC

- Encourages synergism of investigations and operational activities between the IFRC projects.

Position: DOE Pacific Northwest Site Office (PNSO)

Organization: PNSO

Staff Member: David Biancosino

- Works with the ERSD program managers, PNSO, and PNNL to ensure funding and support for the 300 Area IFRC

- Works with ERSD program manager to ensure that field-scale activities are linked to the goals of the ERSD Strategic Plan and DOE-EM

- Helps promote linkages and data dissemination among DOE programs (e.g., other ERSD projects, DOE-EM) and other federal agencies to maximize the success of the IFRC.

Position: DOE EM Richland Operations POC

Organization: DOE Richland Operations

Staff Member: Mike Thompson

- Coordinates with the ERSD program managers, PNSO, and PNNL to ensure support to the 300 Area IFRC

- Works with ERSD program manager to ensure that field-scale activities are linked to the goals of the ERSD Strategic Plan and DOE-RL.

Position: Regulatory Oversight

Organization: Environmental Protection Agency

Staff Member: TBD

- Provides regulatory oversight

- Works with DOE-RL and the ERSD program manager to ensure that field-scale activities are linked to the goals of DOE-EM and Hanford Site cleanup.

Position: River Corridor Contractor

Organization: Washington Closure Hanford

Staff Member: Various

- Performs excavation, recovery, and revegetation via subcontract.

Position: Plateau Remediation Contractor

Organization: $\mathrm{CH} 2 \mathrm{M}$ Hill Plateau Remediation Contract

Staff Member: Chris Wright

- Provides drilling and well decommissioning services via subcontract. 


\subsection{Project Communications}

The 300 Area IFRC project manager is responsible for ensuring that project requirements, risks/hazards, and identified and established controls are communicated internally to project staff and external collaborators. Project risks are documented in the Health and Safety Plan, which is required reading for all active field workers and external ERSD collaborators using the IFRC.

Coordination between 300 Area IFRC investigators and other field activities being conducted in the 300 Area occurs through meetings and conference calls. Participants in field campaigns develop detailed test plans that are posted on the web and "plan of the day" meetings during field campaigns are used to communicate field activities and ES\&H expectations among participants.

A Communications Plan has been prepared for the 300 Area IFRC in accordance with ERSD requirements. The Communication Plan addresses external communication with DOE-SC and DOE-EM, regulators, stakeholders and Tribal Nations. Communication with external entities including the news media is facilitated by PNNL staff in the Communications and External Relations Directorate and coordinated with DOE-SC.

The 300 Area IFRC PI and FSM participate in quarterly conference calls with the ERSD program manager and other staff and provide a quarterly written report. The quarterly report addresses highlights of major scientific accomplishments and publications, lists and explains ongoing activities, lists activities anticipated to occur during the next quarter, and provides a summary of progress and comparison of actual versus projected expenditures, management issues, and interactions with the public and stakeholders. An annual report is prepared that summarizes information in the quarterly reports and progress made by the project each year. Task leads participate in the annual ERSD PIs Meeting to present progress on field experimentation and scientific results. In addition to these scheduled communications, the PI and/or FSM notify the ERSD Program Manager of any unusual events or occurrences by telephone and/or email.

\subsection{Environment, Safety, and Health}

All work on the 300 Area IFRC is performed in accordance with applicable environmental regulations and requirements. Risks impacting the project are associated with experimental field work and environmental management. The project uses policies, standards, requirements and guidelines established at PNNL and documented in its Standards Based Management System (SBMS) to control work at the IFRC. Appropriate requirements are passed on to collaborators at other institutions and to other ERSD investigators performing work at the IFRC.

The project uses a graded approach to ensure that the levels of analyses, documentation, and actions used to comply with requirements are commensurate with the risks and requirements. The objective of this graded approach is to make sure that work efforts are managed through procedures adequate and commensurate with the risk involved in the work effort. Tasks or activities identify their use of a graded approach, where appropriate, in project or activity specific document(s).

The 300 Area IFRC Project subcontracts to national laboratory and university collaborators. Because the work is being performed within the boundaries of a CERCLA remediation site (the 300-FF-1 source operable unit and the 300-FF-5 groundwater operable unit), the requirements of the Price Anderson 
Amendments Act (PAAA) apply. PAAA requirements are included in statements of work, plans, and procedures as appropriate for those working on the site or with potentially contaminated materials. In addition, the project ensures, through project plans and procedures, that occupational radiological protection (10 CFR 835, Subpart B) and safety basis requirements (10 CFR 830.200, Subpart B) are implemented and assessed. A Health and Safety Plan covers work activities in the field and laboratory. Any specific work practices not covered by the Health and Safety Plan require additional job safety analyses and training.

All work is performed in accordance with applicable ES\&H requirements defined in SBMS and with an understanding of safety rights and responsibilities. Staff promptly report accidents, injuries, ES\&H deficiencies, emergencies, and off-normal events through the PNNL single point of contact (375-2400).

Risks associated with experimental and field work include extensive work at the field site location at the northern part of the 300 Area. Samples are shipped from the field site to the nearby 331 building for sample handling, screening analysis, archival, and storage. The laboratory where the samples are received (152) is equipped with double HEPA-filtered hoods, controlled atmosphere chambers, and extensive instrumentation required for safe handling, analysis, and experimentation with contaminated samples. Work conducted in this facility falls under safety provisions within PNNL's Integrated Operations System and PNNL Operating Procedure 331-AF-001. The Health and Safety Plan address potential hazards associated with field work for the project.

The project works with water and sediments with low levels of uranium as well as with common laboratory acids, bases, and salts. These hazards are controlled in accordance with the SBMS subject areas describing working with chemicals, radiological work planning, working with biological materials, and managing wastes.

Upon request, samples are shipped to other ERSD researchers and laboratories that are appropriately permitted to receive contaminated materials following the PNNL SBMS procedure for handling and shipping hazardous materials that meets chain of custody and U.S. Department of Transportation (DOT) requirements.

Twenty-seven of the wells used on the 300 Area IFRC Project have been registered with the Washington State Department of Ecology (Ecology) as Class V Underground Injection Control Wells. The project works directly with a PNNL Environmental Compliance Representative to obtain the required permits and manage the wells in accordance with regulations. Specifically, the project is permitted under Washington State Waste Discharge Permit ST 4511; the project will work with Ecology to ensure that planned discharges during field experiments are covered under the permit.

Project work is performed in accordance with applicable safeguards and security requirements. Foreign nationals participating in field and laboratory activities are cleared for work. This process can take up to several months and experimental plans should take this into account.

\subsection{Quality Assurance Planning}

This section describes the project-specific planning, execution, and assessment of work and controls necessary to provide products/solutions and services of the highest quality consistent with project risks, policies standards and procedures, and the needs, expectations, and resources of ERSD. 
DOE has established, via the PNNL Operating Contract (DE-AC05-76RL01830), that DOE Order 414.1C is the governing quality requirement. In addition, 10 CFR 830, Subpart A is a federal law applicable to DOE facilities. PNNL has chosen to implement a single Quality Assurance Plan (QAP) for work that addresses the requirements of DOE Order 414.1C and 10 CFR 830, Subpart A. The requirements of DOE Order 414.1C and 10 CFR 830, Subpart A are addressed by integration of requirements into the elements of SBMS at PNNL. Because this project is PAAA-applicable, it complies with the applicable requirements in SBMS as the method to meet the 10 CFR 830, Subpart A requirements as outlined in PNNL's DOE-approved Quality Assurance (QA) Program. Details of the project approach to assuring quality are contained in the QA/Quality Control (QC) Plan.

The project manager ensures that activities are conducted in a manner that protects the integrity, repeatability, and client satisfaction with project products, solutions, services, and processes. Work is performed with the level of detail in analyses, documentation, and actions necessary to comply with project quality requirements, the client's expectations, and the PNNL's Quality Program. Key areas of emphasis include, but are not limited to, the following:

- Documentation of calculations, analyses, tests, and software required to substantiate results and processes

- Documentation necessary to substantiate results and processes of project activities.

The established organizational structure, functional responsibilities, levels of authority, and interfaces for those managing, performing, and assessing work necessary to support project QA/QC based on the level of risk identified for the project are outlined in this Field Site Management Plan. Applicable quality requirements are passed on to collaborators, other subcontractors and suppliers, and other ERSD investigators as applicable to the defined work scope.

\subsubsection{Personnel Training and Qualification}

The project employs personnel who are knowledgeable and possess adequate technical, managerial or professional skills to perform their assigned tasks. The project manager identifies any additional specific project-related processes that require project staff training and qualification. In addition, the project maintains documentation for on-the-job training for staff that cannot be tracked in PNNL's training database. Participants working in the field at the 300 Area IFRC are briefed on the Field Site Management Plan, QAP, and Health and Safety Plan.

\subsubsection{Document and Records Management}

The project manager, or delegate prepares, reviews, approves, issues, and revises appropriate project documentation to a sufficient detail necessary to specify requirements, establish designs, support tasks and work processes, and defend conclusions of the project. Where appropriate, these documents are identified as records and maintained by the project. The project has a records custodian to assist with maintaining the project records. The records custodian is responsible for creating and maintaining the project file index and project records inventory. The project manager has ensured there is adequate funding for closing out project files. Project records will be collected and turned over at the end of the project. 
The project manager, or delegate, is responsible for developing any project-specific procedures or permits for technical or work processes. Work processes for maintaining data and assessment controls are identified in the QAP. Documents, including presentations, that are to be released outside PNNL, including to the client, are cleared for release in accordance with PNNL policy and procedures.

The project manager, or delegate, is responsible for developing any project-specific procedures or permits for technical or work processes and ensuring they will be developed and distributed.

\subsubsection{Work Processes}

The project manager, or delegate, identifies when project-specific or task-specific plans, procedures, or permits are needed for technical or work processes. Any project-specific or task-specific plans, procedures, or permits for technical or work processes in use by this project are maintained as part of the project files. The requirements and guidance provided in PNNL procedures will guide project staff in identifying and developing the necessary controls for technical or work processes to:

- Perform work consistent with technical standards, administrative controls, and hazard controls adopted by PNNL SBMS to meet regulatory requirements using approved instructions or procedures

- Identify and control items to ensure their proper use

- Maintain items to prevent their damage, loss, or deterioration

- Calibrate and maintain equipment used for process monitoring or data collection.

\subsubsection{Software}

Software is used to conduct analyses to be delivered, or in support of a deliverable, to the customer. Included in this definition are data analysis tools including spreadsheets and statistical analysis software, databases, and modeling and simulation tools. Excluded are software productivity tools such as word processors and spreadsheets when no automated calculations (e.g., macros, or scripts) are used. This project conducts work in accordance with requirements for the control of software. The QAP describes the documentation and verification activities involving the use of simulation tools on the project.

The project requires the use of databases and software, which are managed, controlled, and operated by entities outside PNNL. The project also requires the use of databases and software that are developed, managed, controlled, and operated by PNNL. A graded approach is used to establish software QA requirements based on identified risk. Software QA at PNNL is based on DOE Order 414.1C, Quality Assurance.

For the purposes of design activities covered by this project, "software" is defined as computer programs including computer programs embedded in firmware. Excluded is software that is an integral part of firmware or equipment, where all software maintenance is performed by the vendor and the software is verified as an integral part of the system (e.g., calibration with known standard materials).

The QAP addresses the details for PAAA-applicable and customer quality-specific software requirements including, but not limited to, the following items: 
- Grading software QA requirements based on risk, safety, facility lifecycle, complexity, and project quality requirements

- Performing safety reviews of software configuration items that are consistent with DOE nuclear safety rules (10 CFR 830)

- Developing procurement controls for acquisition of computer software and hardware

- Applying software QA requirements to software lifecycles

- Documenting and tracking customer requirements

- Managing/controlling software configuration throughout the life cycle

- Performing verification and validation

- Training personnel in the design, development, use, and evaluation of software.

\subsubsection{Data Management}

An important goal of the 300 Area IFRC project is to generate a comprehensive, readily accessible and lasting characterization and experimental database that can be used by project participants, other ERSD investigators, and the science community at large both now and in the future to test various conceptual and numerical models of subsurface transport processes. The data management task implements a central, web-accessible database for all samples, characterization measurements, and experimental data that enables remote collaborative efforts. Raw data, sampling metadata, and instrument calibration are stored to allow an auditable, reproducible link between field measurements and finalized data. Rigorous, workflow-based processes have been established to link field data to numerical predictive models to allow reproducibility. Wells and sensors are linked to an automated data acquisition infrastructure that includes a dedicated wireless network.

Key elements of this approach include:

- A centrally managed data repository. This consists of a number of relational databases that houses all data (geochemical, hydrological, geophysical, microbiological, environmental and experimental) collected as part of the IFRC. These databases contain information on sensors, analytical procedures, and instruments consisting of the raw data and calibration equations used. The repository also holds modeling results encoded in a netcdf format (Rew and Davis 1990).

- A web interface providing access. The web interface allows data access in a tiered manner, permitting IFRC scientists to publish and analyze results from ongoing experiments before the data become publicly accessible. The web interface also includes tools for basic data processing and visualization (e.g., statistical analyses, time series graphing, data contouring and 3D visualization). This is implemented through a scientific workflow system as discussed in Versteeg et al. (2006).

- Automation of data acquisition and data validation. A number of the IFRC wells are equipped with instrumentation allowing for the high temporal density sampling (hourly) of water level, temperature, conductivity, and turbidity. In addition, these systems are designed such that auxiliary sampling probes (e.g., pH, dO and ion-specific electrodes) can readily be integrated. Data from these instruments are transmitted by wireless and parsed into appropriate databases. Data validation is performed to allow for rapid detection of any QA/QC issues. 
- Inventories of solid and liquid samples available to other investigators. A critical aspect of the IFRC research is providing access and highly valuable samples to other ERSD investigators. The availability of such samples, their analytical characteristics, and other research results generated on them are readily traceable and linked through the web interface and associated database.

- Integration of additional data sources. Ongoing regulatory-driven data acquisition at the 300 Area has resulted in considerable data that are used in the overall analyses of experiments performed by the IFRC. In addition, a number of parallel field efforts (e.g., EM-22) will generate useful data that are being integrated into the IFRC database.

The data management component is the responsibility of staff at Idaho National Laboratory. The IFRC Project maintains a website (http://IFRChanford.pnl.gov) that provides access to controlling documentation, site pictures, and general information regarding site history, waste streams, and regulatory status; scientific objectives, goals, and hypotheses; resumes for all participants and their respective statements of work; a copy of the proposal and presentations of different types; an extensive bibliography and pdf files of publications and reports; and other information requested by DOE-ERSD.

\subsection{Site-Specific Project Requirements}

The project manager, FSM, and investigators are responsible for ensuring compliance with ES\&H as well as QA requirements at all stages of the 300 Area IFRC. The project uses the PNNL SBMS as the resource for meeting all applicable requirements. The requirements in SBMS arise from federal and state regulations, executive orders, DOE orders, and compliance and settlement agreements. SBMS contains policies and procedures that comply with these requirements.

The 300 Area IFRC Project has completed the PNNL Electronic Prep and Risk (EPR) Risk Mitigation Permit. The EPR is an electronic tool with a list of questions intended to assist the assessment of project risk in a number of areas including ES\&H, QA, and safeguards and security. It is used to identify and manage relevant risk information related to projects at PNNL. Identified risks are linked to applicable procedures and processes required to mitigate those risks. These EPR risk mitigation actions are intended to facilitate the formal acceptance of project risk levels by PNNL management before full authorization of work. These requirements are passed to participants in the 300 Area IFRC through subcontracts.

The 300 Area IFRC has addressed National Environmental Policy Act (NEPA) compliance through preparation of a categorical exclusion (CX), DOE NEPA CX B3.8, which addresses outdoor ecological and other environmental research. The project has received written approval of the CX from DOE-RL DOE-PNSO to proceed with use of the 300 Area for the IFRC (Appendix B).

\subsection{Permits}

Following identification of the requirements for a particular IFRC activity, any necessary permits or permit modifications are obtained. Variances are obtained for well completions that are outside of Ecology regulations. Discharges to the ground and groundwater are permitted provided they meet the provisions of Washington State Waste Discharge Permit ST 4511. Excavation permits are required for 
drilling wells and the vadose zone experimental plot. Cultural and biological resource surveys are required before initiation of field activities. To the extent possible, permits are obtained for classes of similar activities to lessen the need for modifying permits as conditions for the field experiments change.

\subsection{Training Requirements}

Work conducted at the 300 Area IFRC may fall under the scope of 29 CFR 1910.1450, Hazardous Waste Operations and Emergency Response (HAZWOPER). Personnel working within an exclusion zone, typically around an injection well, will have current HAZWOPER training. All project participants requiring long-term (more than 30 days) access to the IFRC must successfully complete the Hanford General Employee Training and General Employee Radiological Training. The purpose of these training classes is to provide an overview of hazards potentially present at the site, the means used to identify hazardous areas, emergency procedures for the Hanford Site, and policies, procedures, and instructions that apply to all employees. All participants requiring unescorted short-term (less than 30 days) access must review the Hanford Site Visitor Orientation Guide (http://www.hanford.gov/pmm/Downloads/Other/visitorbrochure.pdf).

All personnel accessing the 300 Area IFRC site receive site-specific hazard communication and sitespecific access briefing. Personnel involved with drilling and core extraction require Radiation Worker II training. All personnel working in the field are trained to follow the 300 Area IFRC Health and Safety Plan, and a copy of the plan is maintained at the field site trailer.

\subsection{Transportation Requirements}

Applicable DOT requirements for packaging and shipping of samples are defined in PNNL's SBMS. Based on past experience with sample collection from the vicinity of the 300 Area IFRC, most samples are below the DOT radioactivity limit and are handled as "potentially contaminated" materials. However, the potential to exceed DOE regulations does exist, and in those cases, special provisions are needed. Offsite laboratories receiving samples are required to document that they are appropriately permitted by governing regulatory agencies to handle anticipated radioactivity and other contamination. Sample tracking documentation and sample receipt notification are maintained by the project.

\subsection{Emergency Response}

All injuries/accidents, including exposure incidents, shall be immediately reported to 375-2400 and the Project Manager. The Project Manger or designee will notify PNNL management and the Safety and Health Representative of any incidents. A worker requiring medical attention must be accompanied by another worker to the place of treatment. For cases involving more than simple first aid, or where there is any doubt as to the need for a doctor's opinion, medical attention must be received. For minor cuts and bruises, a first aid kit is available in field vehicles and the field site trailer. Ensuring the availability of safety equipment is the responsibility of the Field Team Leader. For medical assistance or guidance call:

- Advanced Med Hanford First Aid Station

376-3333

- Kadlec Medical Center (emergency room nurse)

946-4611 
Staff shall carry or have a programmed list of phone numbers for points of contact in the office and for emergencies. Staff shall also contact the Field Site Manager and/or Project Manager in nonthreatening situations such as loss of transportation.

- For fire, police, medical emergency or ambulance, call the Single Point of Contact

$375-2400$

- If unable to reach the Single Point of Contact, call Hanford Patrol

$373-3800$

- If unable to reach the Single Point of Contact or Hanford Patrol, call

- Field Site Manager (Mark Freshley)

372-6094

- Project Manager (John Zachara)

376-3254

Staff at field locations on the Hanford Site must also be aware of warning sirens that may be activated and the appropriate actions to take. Wavering Siren: Get in vehicle, call 375-2400 the emergency phone number and follow directions. Howler (AH-OO-GAH): Get in vehicle and leave area.

\subsection{Access for ERSD Investigators Not Participating Directly in the 300-Area IFRC}

PNNL policy requires that use of laboratory resources (e.g., analytical facilities, etc.), DOE equipment (e.g., vehicles, field trailers, and field equipment), and sample storage operations be conducted in accordance with all federal and state regulations, executive orders, DOE orders, and compliance and settlement agreements. Compliance with this policy is implemented by compliance with the projectspecific requirements listed in Section 3.

Because many ERSD investigators are not employees of PNNL, there are additional considerations and requirements for access to the 300 Area IFRC and use of PNNL facilities. Each investigator submits a proposed work plan to the 300 Area IFRC Project Manager and FSM. The FSM and Project Manager review the field work plan along with subject matter experts within PNNL. Issues are resolved with the ERSD PI. After approving the work plan, the FSM and the ERSD PI complete access requirements for visitors to PNNL, including identification of foreign nationals. The processing procedure for foreign nationals can take up to several months, and plans should be made accordingly. The training and other requirements for site access are identified. The ERSD investigators are notified of these requirements by the FSM and must complete the required training before work can be initiated. The review process also identifies the need for any new permits or modifications to existing permits for the 300 Area IFRC.

\subsection{Sample Storage and Management}

In order for research quality samples to be provided for use by the project team and other ERSD researchers, procedures have been established for sample characterization and are described in the Site Characterization Plan. Samples are archived and stored in a manner that is compliant with radiation protection standards. Archived samples are stored in an appropriate facility, including meeting needs for refrigeration. The project maintains documentation of samples in storage and records of samples provided to other ERSD researchers. As described in Section 3.3, DOT transportation requirements are met for samples shipped offsite. 


\subsection{Waste Disposal}

Project-related wastes generated at the IFRC site during operations are treated and disposed. Drilling wastes are handled and disposed of by the drilling contractor and CH2M Hill Plateau Remediation Contract, who will subcontract the drilling for the IFRC. Samples analyzed in the laboratory and used by the project are disposed following PNNL's SBMS subject area for waste management and disposal. Waste disposal costs are included in the project plans for disposition of research materials upon completion of the project.

\subsection{Site Closure}

At the end of research activities at the 300 Area IFRC, the site will be closed and restored. All field equipment will be distributed to other PNNL projects as appropriate. Wells will be decommissioned in accordance with Washington State regulations and the site reclaimed to the original condition at the start of the project.

\subsection{References}

10 CFR 830.200, Subpart A: “Quality Assurance Requirements,” Subpart B, “Safety Basis Requirements.” Code of Federal Regulations.

10 CFR 835, Subpart B, “Management and Administrative Requirements.” Code of Federal Regulations.

29 CFR 1910.1450, "Occupational Exposure to Hazardous Chemicals in Laboratories: Hazardous Waste Operations and Emergency Response (HAZWOPER.).” Code of Federal Regulations.

DOE Order 414.1C, Quality Assurance. U.S. Department of Energy, Washington, D.C.

DOE (U.S. Department of Energy). 1997. Linking Legacies: Connecting the Cold War Nuclear Weapons Production Processes to Their Environmental Consequences. DOE/EM-0319, Office of Environmental Management, U.S. Department of Energy, Washington, D.C.

DOE (U.S. Department of Energy). 1999. From Cleanup to Stewardship. DOE/EM-0466, Office of Environmental Management, U.S. Department of Energy, Washington, D.C.

DOE (U.S. Department of Energy). 2005. 300-FF-5 Operable Unit Limited Field Investigation Plan. DOE/RL-2005-47, Rev. 0, Pacific Northwest National Laboratory, Richland, Washington.

Gephart, R. E. 2003. Hanford: A Conversation About Nuclear Waste and Cleanup. Battelle Press, Columbus, Ohio.

Rew, R. K., and G. P. Davis. 1990. “NetCDF: An Interface for Scientific Data Access.” IEEE Computer Graphics and Applications 10(4): 76-82. 
Versteeg R., A. Richardson, and T. Rowe. 2006. "Web Accessible Scientific Workflow System for Performance Monitoring.” Environ. Sci. Technol.: 10.1021/es0517421 S0013-936X(05)01742-6. 

Appendix A

Contact List for the 300 Area IFRC 



\section{Appendix A}

\section{Contact List for the $\mathbf{3 0 0}$ Area IFRC}

DOE Headquarters

\begin{tabular}{|l|l|}
\hline Name: & David Lesmes, Acting Director \\
Organization: & DOE ERSD \\
Title or IFRC Role: & ERSD Acting Director and Program Manager for 300 Area IFRC \\
Email: & David.Lesmes@science.doe.gov \\
Phone: & 301-903-2977 \\
Fax: & 301-903-4154 \\
Address: & Environmental Remediation Sciences Division \\
& Office of Biological and Environmental Research \\
& SC-23.4/Germantown Building \\
& U.S. Department of Energy \\
& 1000 Independence Avenue, SW \\
& Washington, D.C. 20585-1290 \\
\hline
\end{tabular}

DOE Pacific Northwest Site Office

\begin{tabular}{|l|l|}
\hline Name: & Michael Weis \\
Organization: & DOE PNSO \\
Title or IFRC Role: & Director \\
Email: & michael.weis@pnl.gov \\
Phone: & 509-372-4005 \\
Fax: & 509-372-4532 \\
Address: & Pacific Northwest Site Office \\
& P.O. Box 350 \\
& MS K9-42 \\
& Richland, WA 99352 \\
\hline Name: & David Biancosino \\
Organization: & DOE PNSO \\
Title or IFRC Role: & PNSO Point of Contact \\
Email: & david.biancosino@pnl.gov \\
Phone: & 509-372-4084 \\
Fax: & 509-372-4037 \\
Address: & Pacific Northwest Site Office \\
& P.O. Box 350 \\
& MS K9-42 \\
\hline
\end{tabular}

\section{DOE-RL}

\begin{tabular}{|l|l|}
\hline Name: & Mike Thompson \\
Organization: & DOE-RL \\
Title or IFRC Role: & Groundwater Remediation Project Manager \\
Email: & K M_Mike_Thompson@rl.gov \\
Phone: & 509-373-0750 \\
Fax: & 509-373-1926 \\
Address: & DOE-RL \\
& Central Plateau \\
& P.O. Box 550, A7-75 \\
& Richland, Washington 99352 \\
\hline
\end{tabular}


DOE Office of River Protection

\begin{tabular}{|l|l|}
\hline Name: & Woody Russell \\
Organization: & DOE Office of River Protection \\
Email: & Hanford Site NEPA Compliance Officer \\
Phone: & Woody.Russell@orp.doe \\
Fax: & 509-373-5227 \\
Address: & 509-376-3661 \\
& DOE Office of River Protection \\
& Environmental Compliance Division \\
& P.O. Box 450, H6-60 \\
& Richland, Washington 99352 \\
\hline
\end{tabular}

PNNL

\begin{tabular}{|l|l|}
\hline Name: & John Zachara \\
Organization: & PNNL \\
Email: & Principal Investigator/Project Manager \\
Phone: & John.zachara@pnl.gov \\
Fax: & (509) 376-3254 \\
Address: & (509) 376-3650 \\
& Chemical Sciences Division \\
& Fundamental Sciences Directorate \\
& P.O. Box 999, MS K8-96 \\
Name: & Richland, WA 99352 \\
Organization: & Mark Freshley \\
Title or IFRC Role: & PNNL \\
Email: & Field Site Manager \\
Phone: & Mark.freshley@pnl.gov \\
Fax: & 509-372-6094 \\
Address: & 509-372-6089 \\
& Natural Resources Division \\
& Environmental Technology Directorate \\
& P.O. Box 999, MS K0-36 \\
\hline Name: & Richland, WA 99352 \\
Organization: & Sonia Enloe \\
Title or IFRC Role: & PNNL \\
Email: & 300 Area IFRC Administrator \\
Phone: & Sonia.enloe@pnl.gov \\
Fax: & 509-376-5254 \\
Address: & 509- Chemical Sciences Division \\
& Fundamental Sciences Directorate \\
& P.O. Box 999, MS K8-96 \\
& Richland, WA 99352376-3650 \\
\hline
\end{tabular}




\section{Appendix B}

\section{PNSO and DOE Richland Approval Letters for Use of}

300 Area by IFRC 



\section{Appendix B}

\section{PNSO and DOE Richland Approval Letters for Use of 300 Area by IFRC}

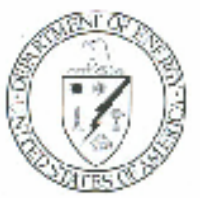

$07-P D-0251$

\author{
Department of Energy \\ Pacilic Nurltıwesl Sile Orfice \\ P.O. Box $350, \mathrm{Kg}-42$
}

Richland, Washingtcn 99352

M:: Michacl Klusc, Intcrim Dircctor

Pacific Northwes: Natioral I.sberarory

Rivhund, Wushirgton 99354

Dear Mr. Kluse:

CONTRACII NO. DE-ACX:5-76RL 01870 -DOF RICIILAND OPERATIONS OFFICE (RI.)

AI'PROV $A \perp$ FOR THE NTEGRATED FIELD-SCALE SUBSURFACE RESEARCI

CHALLENGE (IFC) PROJECT WITHIN THE 300 AREA OF THE HANFORD SITE

Allachod is the RL approval and conditions for the use of the Hanford 300 Area as staled in your proposal cf July 2046 to the Onice ol Biological and Environmertal Rescarch "Multi-Scalc Mass Transfer l'rosesses Controlling Natural Altenualion and Engineered Remediation: An IFC Fonused on Hanford's 300 Area Lranium Plume."

Yeu are authorized to use the site as stated in the altached menrorandun. Any changes ko the proposed work that woukd affoct the conditions of the RL approvel need to be resolved prior to mplementation of those changes. Any and all actixities that result from this work needs to be incluted in the statement of work and budgeted for as part of th is project, inclucling decommissioning of horcholes, and restoration and re-vegetation of disturbed land.

Ir you have any questicns, please contact me, or your stall muy contact Dav d Biancosino, Programs Division, on (599) 372-4084; the RL point of contact for this work is Mike Thompson, (519) 373-0750.

Sincerely.

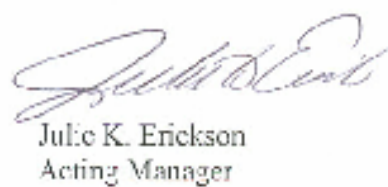

PD:DLB

Acting Manager

Attacimer:

ce wiattach:

M. S. McComick, RL

M. M. Thompson, RL

RECEIVED

MAY 232007

PH:LL COHATTHENT CONTROL

B.1 


$$
\text { RL-F-1330.0 (0) }
$$

\title{
I1:
}

\author{
DATE: MAY 112007 \\ REPEYTO AF: AMCP:KMT:107-AMCP-0158 \\ SLFJECT: U.S: DEPARTMENT OF ENERGY (DOE), RICHLAND OPERATIONS OFFice (RL) \\ APPROVAL FOR THE INTEGRATED FIELD-SCALE SUBSURFACE RESEARCH \\ CHALLENGE (FC) PROJECT WITHTN' THE 300 AREA OF THE HAVVORD SITE \\ To: Julie K. Erickson, Acting Manager \\ Pacific Northiest Site Office
}

The purpose of the memo is to notify the DOE Pacific Nottbwest Site Office (PNSO) that RL hereby grants approval for the IFC project within the 300 Area of the Hanford Site. This approval is granted for the funded life of the IFC, currently schoduled for a period of seven years. This approyal is provided with the und crstanding that one of the kcy objectives of the IFC is to support defensible science-based remediation decisions and subsequent periodic CERCLA five year reviews of the 300 Area records of decision. The FCC team will contdinate their planning and project execution with RL, Fluor Flanford, Inc., and Washington Closure Hanford, LLC. IFC activities are to be planned and executed in a manner such that there is no resultant delay to cleanup activities under the Hanford Federal Facility Agreement and Consent Order. PNSO has line management responsibility for this project and shall ensure compliance with the applicable laws, regulations, and DOE Directives. Activities that could affect the scope or schedule of the River Conjidor Closure Contract must be immediately addressed to RL.

Upon completion of this project, all boreholes and wells drilled by the IFC will be decommissioned by PNSO in accordance writh Washington State requirements unless the facilities roquested remain in service and $R L$ accopts the "ownership" and future docommissioning liability in writing. Any cxcavations or disturbance to re-vegetated areas will also be restored and re-yegetated by PNSO when the work in that area is completed.

Atturched for your information is the Pacific Northwest National Laboratory's proposal "MultiScale Transfer Processes Controlling Natural Attenuation and Engineered Remediation; An TFC Focused on IIanford's 300 Area Uranium Plume, July 2006." 
Mike Thompson, Office of the Assistant Manager for the Central Plateau, (509) 373-0750, is the $\mathrm{RL}$ point of contact for this activity. If there are any questions, please contact me, or your staff may contact, Matt McCormick, Assistant Manager for the Central Plateau, on (509) 373-9971.

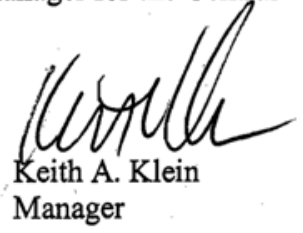

Attachment

cc w/o attach:

S. L. Feaster, WCH

B. H. Ford, FHI

M. D. Freshley, PNNL

D. P. Lesmes, SC-23.4

R. M. Smith, PNNL

J. M. Zachara, PNNL 



\section{Distribution}

No. of

Copies

2 Local Distribution

Pacific Northwest National Laboratory

MD Freshley

K9-33

JM Zachara

K8-96

Distr.1 


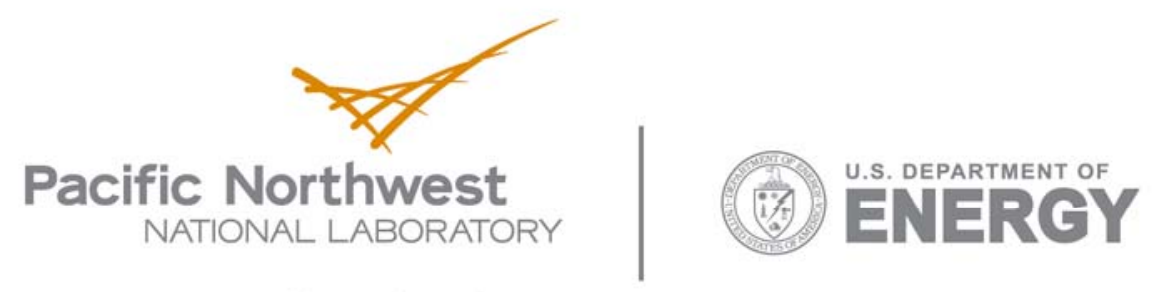

902 Battelle Boulevard

P.O. Box 999

Richland, WA 99352

1-888-375-PNNL (7665)

www.pnl.gov 